2021 (119-120): 55-66.

(c) A szerző(k) 2021

replika.hu/replika/119-120

\title{
Tátrai Viktor
}

\section{H closure fogalma az angolszász és a hazai szociológiában*}

\begin{abstract}
Absztrakt: A tanulmány célja, hogy Randall Collins A piac lezárása és a hivatások konfliktuselmélete címü tanulmányának most megjelenő fordítása kapcsán betekintést nyújtson a closure fogalmának az angolszász szociológiában kialakult különböző jelentésrétegeibe, valamint, hogy bemutassa az eddigi magyar honosításra tett kísérleteket és reflektáljon a fordítás nehézségeire. Ennek érdekében elöször rámutat arra, hogy Max Weber Schließung fogalma jelentős változásokon esett keresztül a Gazdaság és társadalom írása közben, majd röviden bemutatja az ún. neoweberiánus closure theory keletkezési körülményeit és a kapcsolatát Weber eredeti koncepciójával. Az elmélet részletes és átfogó ismertetése helyett Frank Parkin és Raymond Murphy munkáit alapul véve a központi fogalom, a closure jelentésének gazdagodására fókuszál, csak jelezve a fogalom továbbélését és központi jelentőségét a hivatások és a professzionalizáció neoweberiánus megközelítésében. Végül áttekinti az eddigi magyar recepciót és röviden összegzi az új magyar fordítás melletti érveket.
\end{abstract}

Kulcsszavak: Schließung, closure theory, társadalmi elzárkózás, kizárás, piaci lezárás, társadalmi rétegződés, professzionalizáció, neoweberiánus, Weber, Parkin, Murphy, Collins

* A tanulmány A professzionalizáció története. Magyarország a 19-20. században európai kontextusban címü NKFI (sz. 132451) projekt keretében készült. 
Market closure and the conflict theory of professions címü tanulmányában a Randall Collins által használt központi fogalom, a closure értelmezése olyan diszkurzív hagyományban gyökerezik, aminek egymásra rakódó jelentésrétegeit Collins nem fejti ki részletesen, csak utalásokban és hivatkozásokban jelzi, hogy tanulmánya ehhez a tradícióhoz kapcsolódik. Mivel ennek a szociológiai megközelítésnek, illetve elméletnek a recepciójára csak szórványosan került sor a hazai tudományosságban, a magyar olvasóközönség számára hasznos lehet, ha röviden és nagy vonalakban megkíséreljük felvázolni e diszkurzív hagyomány fontosabb állomásait és a honosításra tett eddigi kísérleteket.

Az áttekintés célja továbbá, hogy - ha implicit módon is, de - reflektáljon a Collins tanulmányának magyar nyelvre való átültetése során felmerült néhány problémára. Fordítás és interpretáció viszonya, absztrakt fogalmak szó szerinti és metaforikus, tudományos és köznyelvi jelentéseinek problematizálása, egy konkrét tanulmány és egy szövegeken átívelő diskurzus kapcsolata, fordítói hagyományok és fordítói szabadság olykor konfliktusos viszonya elgondolkodtató kérdéseket és szempontokat vettetek fel a fordítást megelőző kutatócsoportbeli megbeszéléseken. Egy ilyen rövid áttekintés természetesen nem pótolja a tudományos recepciót és nem rendezheti megnyugtató módon a felmerült kérdéseket, de az eredeti kontextus felvázolása hozzájárulhat Collins tanulmányának értelmezéseihez.

Collins többször jelzi, hogy a closure fogalma által fedett jelenség szélesebb körü, mint amit ő tárgyal (Collins 2021 [1990]), és hivatkozásaiból az is kiderül, hogy ennek a fogalmi hagyománynak a gyökerei kétfelé ágaznak. Az egyik ág közvetlenül visszanyúlik Max Weber Schließung fogalmához, amit az 1910-es években a Gazdaság és társadalomban fejtett ki több helyen, és ami a GT angol fordításában closure formátumban került átültetésre. ${ }^{1}$ A másik viszont az 1970-1980-as években az angolszász szociológiában zajló társadalmi rétegződésről szóló vitákhoz, azon belül is az ún. neoweberiánus closure theoryhoz, elsősorban Frank Parkin és Raymond Murphy munkáihoz kapcsolódik. A closure fogalmának természetesen utóélete is van Collins három évtizede írt tanulmányához képest: az a mai napig domináns szerepet játszik a professzionalizációs elméletek neoweberiánus megközelítéseiben (Swedberg és Agevall 2016 [2005]: 224). ${ }^{2}$

\section{Max Weber Schließung fogalmának kidolgozása}

Kerülni akarván a Weber-exegézis buktatóit, annyit mindenképpen szükséges leszögezni, hogy a Schließung fogalma Weber különböző időpontban írt szövegeiben - nem

1 A Gazdaság és társadalom különböző nyelvü kiadásaira a bevett gyakorlat szerint a mü kezdőbetüit tartalmazó rövidítéssel utalok $(\mathrm{GT}, \mathrm{WuG}, \mathrm{EaS})$. A részletes bibliográfiai adatokat lásd a hivatkozott irodalmak közt. Mivel ennek a tanulmánynak az első fele alapvetően a Weber által a GT írása közben kidolgozott Schließung fogalom angolszász recepciójának és hatásának áttekintéséről szól, igyekeztem a következő elvet szem előtt tartani: amikor a fogalom weberi koncepciójáról írok, akkor a német Schließung formát használom, amikor annak angolszász recepciójáról, akkor az angol fordításhoz, vagyis a closure formátumhoz tartom magamat. Idézetek esetén természetesen az idézett szöveg nyelve a döntő. A dőlt betűs kiemelések tőlem származnak, ellenkező esetben jelzem, hogy az idézet tartalmazta.

2 A neo-Weberianism címszó mellett felhasználtam még: az action, class, collegiality, occupation (Beruf), open and closed relationship, profession (Beruf), status (Stand) és a vocation (Beruf) címszavakat. 
meglepő módon - jelentős változásokon ment keresztül. A legrészletesebb kimunkálást természetesen az „utolsó szóban”, az 1919-ben írt Szociológiai kategóriatanban, a Nyitott és zárt kapcsolatok címü 10. \$-ban kapta, de a „nyitott” és „zárt” kapcsolatok megkülönböztetése már az 1913-ban megjelent Logos-cikkben is feltünik (Weber 2003 [1913]: 165). Ebben a korai írásban - melynek a második része eredetileg azzal a szándékkal készült, hogy „módszertani megalapozást” nyújtson a GT számára - még kidolgozatlan formában és más kontextusban szerepel: az egyetértésen alapuló (közösségi) cselekvés tárgyalásánál kerül elö. ${ }^{3}$ A closure fogalma azt az értelmét, amire később a neoweberiánusok (így Collins is) hivatkoztak, a GT második részében a közösségek gazdasági kapcsolatait általában tárgyaló fejezet 2. §-ában („Nyitott” és „zárt” gazdasági kapcsolatok) nyerte el (EaS 341-343, GT 2/1. 38-41).

Weber a következőképpen ismerteti a problémát: ha valamilyen okból a szerzési esélyek csökkennek, akkor a konkurenciában részt vevők érdekévé válik, hogy korlátozzák a versenyt. „A korlátozás abban a formában szokott megtörténni, hogy a (tényleges vagy potenciális) konkurensek egy részét valamilyen kívülről megállapítható ismertetőjegyüket alapul véve - fajuk, nyelvük, felekezetük, térbeli és szociális értelemben vett eredetük, származásuk, lakóhelyük stb. alapján - a többiek igyekeznek kizárni a versenyből (Ausschluß vom Mitbewerb)" (GT 2/1. 38-39, WuG 201). Ezt Weber közösségi cselekvésnek hívja (Gemeinschaftshandeln). Ha az érdekek tartósan fennállnak, akkor érdekközösségek (Interessentengemeinschaft) jönnek létre, amelyek törekednek racionális renddel biró társulássá (Vergesellschaftung mit raionaler Ordnung) válni. A következö lépés, hogy ök, vagy egy politikai közösség, amire befolyással bírnak, „lefektet egy rendet (Ordnung, az angolban legal order), amely monopóliumokkal korlátozza a versenyt". Ekkor az érdekközösség (Interessentengemeinschaft) már jogi közösséggé (Rechtsgemeinschaft, az angolban legally privileged group) válik. Ezt az egész folyamatot a közösségi cselekvéstöl kezdve a jogi közösséggé válásig hívja Weber Schließungnak, amit az angolok closure-nek fordítottak. ${ }^{4}$

3 „Az a kérdés, hogy egy egyetértésen alapuló cselekvés (Einverständnishandeln) »nyitott« (offen) vagy »zárt«-e (geschlossen), és ha zárt, milyen mértékben az - vagyis, hogy mindenkor mindenki részt vehet benne, aki akar, vagy a résztvevők pusztán egyetértés alapján, esetleg társulással lehetetlenné tehetik kívülállók számára a bekapcsolódást -, az mindig az egyes esetben dől el. Egy konkrét nyelvi közösségnek vagy piaci közösségnek (Marktgemeinschaft) mindenkor megvannak a maga (többnyire elmosódó) határai. [...] a nyelvi közösség résztvevőinek például nem füződik érdekük ahhoz, hogy a kívülállókat kizárják (Ausschluß) az egyetértésből (az persze nagyon is érdekükben állhat, hogy a körülményektől függően kizárják őket egy konkrét beszélgetésből), és a piacon érdekelt felek (Marktinteressenten) is gyakran éppen a piac »bővitésében« érdekeltek. De azért egy nyelv (mint szakrális, rendi vagy titkos nyelv), valamint egy piac (ein Markt) - egyetértés, illetve társulás folytán - monopoljelleggel (monopolistisch) "zárt (geschlossen) is lehet." A magyar fordítást Erdélyi Ágnes készítette és látta el jegyzetekkel (Erdélyi 2003: 109-217, idézet helye: 165-166), a némettel az 1922-ben megjelent kiadás (GAW 1922: 403-450) alapján vetettem egybe. Érdemes észrevenni, hogy itt a nyitottság és zártság még hol a (közösségi) cselekvésre, hol a közösségre vonatkozik. Ennek az lehet az oka, hogy a társadalmi kapcsolat (soziale Beziehung) fogalmát - ami az 1919-es kategóriatanban köztes kategóriaként majd összeköti a társadalmi cselekvés (soziales Handeln) fogalmát a közösség (Vergemeinschaftung,) illetve a társulás (Vergesellschaftung) fogalmával - 1913-ban még nem dolgozta ki. Bővebben lásd: Erdélyi (2003: 13-38 és 185-217).

4 „Dieser Prozeß der "Schließung" einer Gemeinschaft, wie wir ihn nennen wollen, ist ein typisch sich wiederholender Vorgang (...)" (WuG 201); „Such closure, as we want to call it, is an ever-recurring process (...)” (EaS 342). Azért volt fontos ilyen részletességgel, lépésről lépésre ismertetni Weber koncepcióját, mert így kiválóan látszik, hogy szinte ugyanazokon a szinteken halad végig, mint amikből majd 1919-ben megalkotja a szociológiai kategóriatan architektúráját. Utóbbira lásd Erdélyi (2003). 
Weber a folyamat felvázolása és a példák felsorolása után megadja a definíciót is:

A szerveződésnek ilyen esetekben mindig az a törekvés a hajtóereje, hogy a résztvevők monopolizáljanak bizonyos gazdasági esélyeket, és ez a törekvés olyan más pályázók ellen irányul, akik valamilyen közös - pozitív vagy negatív - ismertetőjeggyel jellemezhetők. A cél mindig a kívülállókkal szembeni elzárkózás: az, hogy a kívülállókat valamilyen mértékig kizárják a szóban forgó (társadalmi és gazdasági) esélyekből. Az elzárkózás - ha sikerrel jár nagyon különböző mértékű lehet (kiemelés az eredetiben - GT 2/1. 39). ${ }^{5}$

A szociológiai kategóriatanban Weber, immár teljes fogalmi apparátussal felvértezve, még következetesebben és részletesebben dolgozta ki koncepcióját. A szakasz jelentőségét nem csak azáltal nyeri el, hogy a Schließung fogalmával alapozza meg a „társadalmi kapcsolat” és a „szervezet” közti átmenetet, de a „tulajdon” fogalma is itt jelenik meg először, a zárt társadalmi kapcsolatból levezetve. Összefoglalóan tehát azt mondhatjuk, hogy a weberi fogalom kidolgozása már az 1913-as Logos-cikkben elkezdődött, végső formáját az 1919-es kategóriatanban nyerte el, de részletes kimunkálására a kettő között került sor a GT „érdemi részének” írásakor a nyitott és zárt gazdasági kapcsolatokról szóló fejezetben, és föleg ez utóbbi hatott a neoweberiánus szociológusokra. ${ }^{6}$ A következő lépésben azt kell tisztáznunk, hogy mire használták fel és milyen jelentést nyert Weber fogalma az 1970-80-as évek angolszász szociológiájában.

\section{A neoweberiánus closure theory}

Erdélyi Ágnes monográfiája az 1960-as évekig mutatja be az angolszász Weber-recepció történetét, vagyis nagyjából ott marad abba, ahol nekünk fel kéne venni a fonalat (Erdélyi 1993). A neoweberiánus closure theory keletkezésével kapcsolatban az egyik legkülönlegesebb körülmény, hogy ha feltennék a kérdést, ki az elmélet atyja, nem biztos, hogy bárki is magára vállalná azt: inkább csak egymásra mutogatás történne. A keresztapa figurája viszont egyértelmüen azonosítható: először Raymond Murphy kanadai szociológus „fedezte fel”, hogy az 1970-es években különböző neoweberiánus szerzők némileg eltérő fogalmi apparátussal, de egyaránt Weberből kiindulva, ugyanarról a jelenségről beszélnek, és ő keresztelte el neoweberiánus closure theory-nak ezt a megközelítést. Murphy szerint az elmélet kidolgozása elsősorban a brit Frank Parkinnak és az amerikai Randall Collinsnak köszönhető (Murphy 1983: 641). Parkin érdemének tartja, hogy „feltámasztotta” a „halott és elfelejtett fogalmak temetőjéből” Weber „social closure” koncepcióját, de elismeri, hogy Parkin a saját hozzájárulását nem tartotta új elmélet megalkotásának (Murphy 1983: 631-632). Collinsszal fordított a helyzet: ő ambicionálta az elméletalkotói szerepkört, és bár Murphy „fő közreműködőként” aposztrofálja őt is, Collins még csak

5 „Und das Ziel ist: in irgendeinem Umfang stets Schließung der betreffenden (sozialen und ökonomischen) Chancen gegen Außenstehende. Diese Schließung kann, wenn erreicht, in ihrem Erfolg sehr verschieden weit gehen” - WuG, 202. "This monopolization is directed against competitors who share some positive or negative characteristics; its purpose is always the closure of social and economic opportunities to outsiders" - EaS, 342. (kiemelések az eredetiben)

6 Írásaikban gyakran visszatérő hivatkozások találhatók még „a piaci társulások” (GT 2/1. 325-330) és az „osztályok, rendek, pártok" (GT 2/3. 32-45) címü fejezetekre. 
nem is használta az 1970-es években írt publikációiban a closure kifejezést, inkább „konfliktuselméletként" (conflict theory, conflict paradigm) hivatkozott a saját megközelítésére. Ezek után Murphy megállapítja, hogy bár a felszínen a weberiánus „closure theory” aligha tűnik egységes megközelítésnek - hiszen az elméletalkotók nemcsak önállóan dolgoztak, hanem ignorálták is egymás publikációit -, nem szabad, hogy ezek a tények elvakítsanak: mindketten ugyanarról a problémáról írtak (Murphy 1983: 632 és 653).7

Murphy egyik célja, hogy kimutassa, Weber, Collins és Parkin munkássága „egy összefüggö egészet” alkot, és hogy a closure theory egy „átfogó”, „általános szociológiai problémára” adott válasznak tekinthető (Murphy 1983: 632). ${ }^{8}$ Először tehát azt érdemes tisztázni, hogy ha ez így van, miért beszélünk külön-külön Weber closure fogalmáról és a neoweberiánus closure theoryról, és ehhez azt kell megérteni, hogy mi volt a neoweberiánusok eredeti szándéka azzal, hogy visszanyúltak Weber fogalmához, mire akarták felhasználni azt.

Parkin 1974-ben publikálta első cikkét, amelyben „feltámasztotta” a Webertől eredő closure fogalmát, és - feltárva a mainstream irányzatok problémáit - világosan leszögezte, hogy ő az osztályelemzés egy alternatív megközelítését kívánja nyújtani, amit „embrionális formában" tartalmaz csak a Webertől átvett social closure fogalma. Azt is világossá tette, hogy ő Weber koncepcióját „finomítja” és „kibővíti”, az eredeti fogalomhasználatot „eltorzítja” (Parkin 1974: 3-4). ${ }^{9}$ Parkin összegző monográfiája 1979-ben jelent meg, és már a címe is egyértelművé tette, hogy mire akarta felhasználni Weber fogalmát (Parkin 1979). Murphy a 80-as évek elején kezdte el sorra publikálni tanulmányait, amiket a Weber-Parkin-Collins-féle closure theory kritikai méltatásának szentelt: ezekben feltárta a neoweberiánus koncepció hiányait, és javaslatokat tett az elmélet kibővítésére (Murphy 1983, 1984, 1985, 1986a 1986b). ${ }^{10}$ Világos tehát, hogy már Parkin is a kezdetektől fogva eltért Weber fogalmától, Murphy pedig tovább haladt ezen az úton, így fontos megérteni a különbségeket, az egymásra rakódó jelentésrétegeket.

Mint említettem, ez az áttekintés nem helyettesítheti a tudományos recepciót, így csak néhány nagyon rövid megjegyzésre van lehetőség. Murphy azt írta 1983-as tanulmányában, hogy az 1960-70-es években úgy tünt, hogy két általános szociológiai elmélet, a marxista osztályelmélet és a funkcionalista rétegződéselmélet „monopolizálta a szociológiai gondolkodást", így az uralkodó elméletek korlátainak felismerésére adott válaszként és hegemóniájuk megtörésére tett kísérletként kontextualizálta a neoweberiánusok színre lépését. A neoweberiánusok az 1970-es évek angolszász szociológiai diskurzusában tehát a funkcionalista-konfliktuselméleti fö törésvonal konfliktuselméleti oldalára helyezkedve, de a (neo)marxistákkal szemben határozták meg magukat, így egyszerre kritizálva mindkét mainstream irányzatot. ${ }^{11}$ Számukra a closure weberi fogalmának felújítása azt a célt

7 Elkerülte Murphy figyelmét Collins egyik recenziója, amiben pozitívan írt Parkin tanulmányáról (Collins 1976).

8 Még két szerzőt említ Murphy, akik hozzájárultak a closure problematikához: Gertrud Neuwirth és Pierre Bourdieu egy-egy tanulmányát illeszti bele a koncepciójába. Murphy felfogásában Bourdieu elemzése a tudományos érvényesülés társadalmi feltételeiről, vagy Collins munkái a kredencializmusról a Weber és Parkin által kifejlesztett általános érvényű closure theory speciális eseteit dolgozza fel (Murphy 1983: 638 és 653).

9 Reinhard Bendix az Egyesült Államokban Parkinnal egy időben fedezte fel Weber closure fogalmának jelentőségét az osztályképződés szempontjából, de nem dolgozta ki (Bendix 1974).

10 Tanulmányait Murphy 1988-ra kötetbe rendezve és kiegészítve adta ki a Collins által is hivatkozott Social Closure: The Theory of Monopolization and Exclusion címü könyvét.

11 A „kirívóan antimarxista” retorika inkább az Angliában élő Parkinra volt jellemző, Murphy és Collins a funkcionalistákban látta a fö ellenfelet. 
szolgálta, hogy (1) az osztályképződés vizsgálata során ne elöre meghatározott, elvont kategóriákba kelljen bepréselni az onnan többé-kevésbé kilógó csoportokat (pl. fehérgalléros munkások, hivatások stb.), hanem az empirikusan vizsgálható társadalmi csoportok egymáshoz való viszonya alapján lehessen kialakítani osztálykategóriákat, (2) differenciáltabb, többdimenziós szempontrendszert lehessen bevonni az egyenlőtlenségek elemzésbe (pl. etnikai, vallási, kulturális szempontok), (3) azonos fogalmi apparátussal lehessen elemezni a kapitalista és a szocialista társadalmak struktúráját, valamint az osztályok közötti és az osztályokon belüli társadalmi differenciálódást. Ezek voltak azok a szempontok, amik miatt Parkin a társadalmi rétegződés alternatív magyarázatának megalkotásához visszanyúlt, és a saját problémáihoz igazítva módosította Weber fogalmát, holott elismerte, hogy Weber koncepciója nem kapcsolódott közvetlenül a rétegződéselméletéhez (Parkin 1974: 4). Lássuk Parkin és Murphy néhány fogalmi és elméleti újitását.

Parkin felfogásában a social closure a hatalom mozgósításának eszköze, egy kollektív társadalmi cselekvés, amin belül kétféle, egymással ellentétes ideáltipikus stratégiát különít el: a kirekesztést (exclusion) és az elbitorlást (usurpation) (Parkin 1979: 44-45). ${ }^{12}$ Elöbbit tartja minden társadalmi rendszerben a fö formának, melynek célja más társadalmi csoportok alávetése. A két stratégia fő különbsége, hogy a kirekesztés során a hatalomgyakorlás iránya - metaforikusan kifejezve - fentről lefelé történik, míg az elbitorlás során éppen ellenkezőleg. További fontos különbség, hogy a kirekesztés stratégiájához gyakran sikerül megszerezni az állam támogatását, ami az elbitorlás esetén se lehetetlen, de nem jellemző. Az alávetett csoportok maguk is élhetnek a kirekesztés stratégiájával más csoportok irányában, ami megtöbbszörözi az „alrétegek” számát, de folyamodhatnak az elbitorlás stratégiájához is. Parkin szerint a társadalmi rétegződés fö törésvonala ott található, ahol a social closure stratégiája szükségszerüen vált át kirekesztésből elbitorlásba, mert az erőforrásokhoz való hozzáférés másként már lehetetlen. A kirekesztés, és így az alávetés történhet a csoportjellegzetességek alapján, vagyis kollektivista szabályok szerint, vagy individualista elvek alapján, aminek legjellemzőbb formája a kredencializmus, vagyis az állások betöltésének bizonyos iskolai bizonyítvány megszerzéséhez történő kötése. Parkin szerint végső soron a „social closure teljessége határozza meg az elosztási rendszer általános jellegét" (Parkin 1979: 44).

Murphy számos tanulmányában méltatta Collins és Parkin munkásságát: „Az egyik legeredetibb válasz az uralkodó társadalomelméletek korlátaira egy új, általánosabb megközelítés létrehozására tett kísérlet volt, amely képes megragadni az uralom alapjainak sokféleségét." Ennek a megközelítésnek a forrása Weber social closure fogalma, amivel egyszerre elemezhető a „piaci monopolizáció” és a „hatalom és lehetőségek monopolizációjának egyéb formái” is (Murphy 1984: 548). Az elismerés mellett Murphy a closure theory jó néhány elméleti és fogalmi fogyatékosságra is rámutatott, és ezek javítására javaslatokat fogalmazott meg. Ezek közül csak azt ismertetem röviden, ami a closure 1990-es évekre kialakult neoweberiánus jelentéséhez közvetlenül kapcsolódik.

Murphy kritizálta Parkint, mert „azt állítja, hogy a modern kapitalizmusban a kizárásnak (exclusionary closure) két fó formája létezik: az első a tulajdon intézményein alapul, amelyek korlátozzák a termelés eszközeihez és gyümölcseihez való hozzáférést, a másik

12 Az 1974-es tanulmányában az elbitorlást még szolidarizmusnak (solidarism) nevezte el (Parkin 1974: 4 és 9-12). A tanulmány magyar fordítását lásd: Parkin (2013 [1974]). 
pedig a tudományos és szakmai képesítéseken és iskolai végzettségeken alapul, amik a munkamegosztás kulcspozícióiba való belépést korlátozzák" (Murphy 1984: 552). Murphy vitatja, hogy ezek egyforma jelentőségüek lennének, mint ahogy azt Parkin sugallja (Parkin 1979: 54 és 58). A központi hiányosság, amiből ez a probléma fakad és ami Weber, Collins és Parkin elméletére is igaz, hogy „egyik változat sem nyújt koherens felfogást a closure különböző szabályai közötti kapcsolatokról, egyes closure szabályok elsőbbségéről másokkal szemben, vagy arról, hogy az elsőbbség kérdése hogyan változik különböző típusú társadalmakban", ezért Murphy megkülönböztetést javasol a kirekesztés primer (elsődleges), derivatív (leszármaztatott) és esetleges formái közt (Murphy 1984: 555): ${ }^{13}$

A kirekesztés primer formája a kizárási szabályok azon együttesére utal, amelyet az állam jogi (és így végső soron katonai) apparátusa támaszt alá, és ezért a társadalomban a hatalomhoz, az erőforrásokhoz és lehetőségekhez való hozzáférés vagy az azokból való kizárás legföbb meghatározója. (...) A kirekesztés elsődleges formáját, amely köré a társadalom szerveződik, nemcsak hatásainak különös fontossága különbözteti meg, hanem az a tény is, hogy uralja és függővé teszi a kirekesztés egyéb formáit (Murphy 1984: 555).

Ebből következik, hogy Murphy szerint az különbözteti meg a kapitalista, az arisztokratikus és a szocialista társadalmakat, hogy a kirekesztés fő formái eltérőek ezekben a társadalmakban. ${ }^{14}$ A kirekesztés derivatív és esetleges formáját a fö formához való viszonyuk alapján különíti el egymástól. A derivatív forma „a társadalmi lehetőségek monopolizálásának olyan szabályai, amelyek közvetlenül a kirekesztés primer formájából származnak, de mégsem azonosak vele”. Ezeket törvénybe iktathatják (pl. faji szegregációs törvények), de erre nincs feltétlenül szükség, amennyiben pl. a magántulajdon jogi formájára való hivatkozással is létrehozható a kizárás pl. a magánklubokból, elit magániskolákból stb. való kirekesztés faji, nemi, vallási stb. alapon (Murphy 1984: 555-556). Az esetleges formák a kizárás fennmaradó szabályai, amelyek „noha nem közvetlenül a primer formából származnak, a kizárás ezen szabályainak létezése és jellege attól a kontextustól függ, amelyet a primer forma dominál" (Murphy 1984: 557). Murphy szerint a kirekesztés feltételes formáit ugyan gyakran, de nem feltétlenül támogatja az állam jogi apparátusa. ${ }^{15} \mathrm{Az}$ elbitorlásnak (usurpation) is megkülönbözteti két formáját Murphy, mégpedig az alapján, hogy hogyan viszonyulnak a fennálló struktúrákhoz: az inkluzívet (inclusionary) és a forradalmit (revolutionary). Előbbire példák a szakszervezetek gazdasági jellegű harcai vagy a polgárjogi mozgalmak, utóbbira viszont az a jellemző, hogy a struktúra megváltoztatására törekednek, mint például a munkásság forradalmi jellegű mozgalmai, amelyek a kapitalizmust akarják eltörölni (Murphy 1984: 560-561).

13 Murphy elfogadja Parkin felosztását, hogy a social closure két ellentétes irányú stratégiája a kirekesztés, kizárás (exclusion) és az elbitorlás (usurpation). Ezek a kategóriák (forms of exclusion) tehát az előbbi alkategóriái. Az eredeti kifejezések: principal, derivative, contingent.

14 A kirekesztés fö formái a kapitalista piacgazdaságban a jogilag intézményesített magántulajdonon, az arisztokratikus társadalmakban a leszármazáson, a szocialista társadalmakban pedig a kommunista párthoz való viszonyon alapulnak Murphy szerint.

15 Murphy a kirekesztés különböző formáinak (forms of exclusion) egymáshoz való viszonya alapján a kirekesztési struktúrák (structure of exclusion) három típusát is megkülönbözteti a modern világban: tandem struktúrát (pl. nyugati kapitalista államok), duális struktúrát (pl. apartheidrendszer) és poláris struktúrát (világgazdasági rendszer) határol el, de ezek ismertetése most nem szükséges (Murphy 1984: 558-561). 
Ebből a rövid ismertetésből is látható, hogy Weber closure fogalmát a neoweberiánus szociológusok megpróbálták kiterjeszteni a társadalmi egyenlőtlenségeket magyarázó átfogó elméletté. Amíg Webernél a closure fogalmának mikroszociológiai vonatkozása van, addig Parkinnál és Murphynél már makroszociológiai folyamatok modellezésére szolgál. Talán ez az egyik oka, hogy a professzionalizációval foglalkozó szociológusok elöszeretettel használják: a fogalomnak ez a mikro-makro természete megkönnyíti a léptékváltást. A closure fogalma a professzionalizációval foglalkozó szakirodalom - különösen a neoweberiánus megközelítés - egyik leggyakrabban használt metaforájává vált az elmúlt harminc évben (Harrits 2014; Liljegren 2017; Agevall 2017). „Az a sajátos neoweberiánus megközelítés, amit ez a tanulmány szorgalmaz - írja Mike Saks 2010-es tanulmányában -, kifejezetten azon a jellegzetességen alapul, hogy a hivatásokat a jogilag megalapozott kizárásra (exclusionary closure) alapozva definiálja" (Saks 2010: 892, 2012: 4). Mivel ez az adaptáció jórészt Collins tanulmányának megjelenése után következett be, itt most nem térhetünk ki rá bővebben. ${ }^{16}$ Iggy is látható, hogy a Weber által útjára indított closure fogalma jelentős karriert futott be az elmúlt évszázadban, ennek következtében jelentős változásokon ment keresztül.

\section{Felemás recepció és fordítási nehézségek}

Teljes képet a magyarországi recepcióról sem adhatunk, csak a főbb momentumokat veszszük sorra. Frank Parkin munkássága már az 1970-es évek közepén figyelmet keltett a magyar szociológusok körében, beleértve a social closure koncepcióját is. Andorka Rudolf, aki a „neoweberiánus és az empirikus szociológusokat” tartotta „,intellektuális rokonainak" (Andorka 2006b: 27), valószínűleg az 1974-es torontói szociológiai világkongresszuson figyelt fel Parkinra, és 1976-tól bizonyíthatóan hivatkozott müveire. Tudható, hogy mindketten részt vettek az eseményen (Farkas 1975), és Andorka később utalt Parkinnak az ott elhangzott, de publikálatlanul maradt előadására, amelyet valószínűleg kéziratban kaphatott meg. Az elhangzott elöadás szövegét nem ismerjük, de Parkin minden bizonynyal a social closure elméletét is ismertette. ${ }^{17}$ Andorka az 1982-ben megjelent A társadalmi mobilitás változásai Magyarországon címü máig alapvető jelentőségü monográfájában Parkinnak több munkájára is hivatkozott, többek közt az 1974-ben megjelent tanulmányára is, amelyben Parkin először publikálta social closure elméletét. Mivel ekkor még se Webernek, se Parkinnak nem volt magyar fordítása, így Andorka „társadalmi kizárásnak” fordította a fogalmat. ${ }^{18}$ „Parkin is »az osztályelemzés alternatív útját « keresve használja fel Weber »társadalmi kizárás« fogalmát. Ez azt jelenti, hogy bizonyos társadalmi osztályok kizárják a »kívülállókat« abból, hogy az előnyös gazdasági és társadalmi körülményekhez hozzájussanak" (Andorka 1982: 11). Nem hivatkozott viszont Andorka Parkinnak a

16 Eliot Freidson a hivatások elleni „ideológiai támadásnak” minősítette a closure theoryt (Freidson 2001: 197-206).

17 Raymond Murphy, aki a torontói egyetemen szerezte szociológiai doktorátusát, és aki az 1980-as évekig oktatásszociológiával foglalkozott (ezen keresztül ismerkedett meg Collins munkásságával), 2012-ben egy interjúban úgy nyilatkozott, hogy őt is Parkinnak a kongresszuson elhangzott előadása inspirálta, hogy a social closure elméletét kidolgozza. https://www.csa-scs.ca/files/webapps/csapress/environment/feature-profile-april-2012/ [letöltés: 2021. 04. 04.]

18 A „társadalmi kizárás” fordítást 2006-os monográfiájában is megtartotta (Andorka 2006a: 163-164). 
social closure elméletét összefoglaló 1979-ben megjelent monográfiájára, de nem zárható ki, hogy ismerte. A 70-es évek magyar szociológiájának politikai helyzetét tekintetbe véve (Andorka 1990, 1996: 114, 2006a: 157-170) valószínűbb, hogy a címe miatt kerülte az explicit hivatkozást.

Azok a szociológusok, akik ekkoriban a társadalmi rétegződést kutatták, többnyire mind ismerték és hivatkoztak Parkin munkáira (Szelényi 1983; Kolosi 1987; Horváth 1988), de a closure fogalma Szelényinél és Kolosinál nem jelent meg, Horváth Ágnes viszont Andorkához hasonlóan kizárásnak fordította azt. A 90-es évek elején Somlai Péter a szociális zárlat fordítást javasolta kifejezetten Parkin 1974-es tanulmányára hivatkozva (Somlai 1993: 90). Talán ez is befolyásolta Feleky Gábort, aki az 1960-1980-as éveknek a fehérgalléros dolgozók társadalmi helyzetéről szóló szociológiai megközelítéseit és vitáit tárgyaló tanulmányában Parkin social closure elméletét ismertetve társadalmi zárlatnak fordította azt (Feleky 1996: 9-11). ${ }^{19}$ Tardos Róbert nemrég megjelent tanulmányában, szintén Weberre és Parkinra utalva ugyancsak kizárásnak fordította a closure fogalmát (Tardos 2015).

Az eddig ismertetett adaptálási kísérletektől meg kell különböztetnünk Böröcz József tanulmányait, aki eredetileg 1997-ben angol nyelven megjelent munkájában ugyan a social closure fent tárgyalt irodalmából kiindulva, de egy új kontextusba ágyazva kifejezetten arra törekedett, hogy új, a korábbiaktól eltérő jelentéssel ruházza fel a fogalmat, és erre vezette be a contingent closure kifejezést (Böröcz 1997: 235-241, 2001: 1156-1161). ${ }^{20}$ Tanulmányának magyar fordítása 2017-ben jelent meg, a fordító, Laszkács Ágnes a social closure fogalmát társadalmi zárként, a contingent closure fogalmát pedig a "feltételes társadalmi kirekesztés és beengedés" terminussal próbálta visszaadni (Böröcz 2017 [1997]). A Böröcz József által kidolgozott fogalmakat legutóbb Éber Márk Áron használta fel a Replikában 2020-ban publikált hozzászólásában, követve a Laszkács Ágnes-féle fordítás kifejezéseit. ${ }^{21}$

Az eddig tárgyalt magyar szociológiai szakirodalom olyan munkákat jelentett, amelyek csak hivatkoztak az eredetileg angol nyelven zajló diskurzusra és annak központi fogalmára, a closure-re. Készült azonban néhány fordítás is az eredeti szövegekről - ha nem is sok. Eddig kettő jelent meg: Erdélyi Ágnes Gazdaság és társadalom fordítása és Berényi Eszter munkája Parkin 1974-ben írt tanulmányáról. Erdélyi Ágnes németről fordította magyarra Weber magnum opusát, ő a „Nyitott” és „zárt” gazdasági kapcsolatok címü fejezetben - mint már említettük - elzárkózásnak fordította vagy körülírta („zárt körüvé válás") a Weber által használt Schließung kifejezést, ami az angol fordításban closure formátumban jelent meg. Berényi Eszter Parkin 1974-es tanulmányát fordítva - talán éppen Erdélyi Ágnes fordításához igazodva - szintén társadalmi elzárkózásnak fordította a social

19 Nagy J. Endre is utal Parkin és Weber „zártság” fogalmára, amivel valószínűleg a closure-t akarta visszaadni, de ez nem teljesen egyértelmű a szövegkörnyezetből, a pontos hivatkozás pedig hiányzik (Nagy 2003: 77).

20 Aminek jelentése tehát nem egyezik a Murphy által használt contingent forms of exclusion vagy contingent forms of closure fogalmakkal.

21 2002-ben a Replikában megjelent Böröcz József egy másik tanulmánya is, ami eredetileg szintén angol nyelven íródott (és mivel nincs fordító feltüntetve, vélhetően maga a szerző fordította). Ebben a contingent closure fogalma feltételes társadalmi kizárás és beengedés-ként szerepel (Böröcz 2002: 136), vélhetően ehhez igazodott Laszkács Ágnes későbbi fordítása. 
closure kifejezést, míg az exclusion értelmét a kirekesztés, a solidarism jelentését pedig a szolidarizmus szóval próbálta visszaadni (Parkin 2013 [1974]).

A fenti áttekintésből is látható, hogy a closure magyar nyelvre való átültetésének nincs kizárólagos hagyománya, így a most publikált Collins-tanulmány esetében a fordítók úgy találták, hogy a lezárás kifejezéssel tudják a legjobban visszaadni az eredeti szöveg értelmét. A korábbi fordításoktól való eltérés mellett szólt többek közt az a megfontolás, hogy az angol nyelvü diskurzusban a closure és az exclusion közti kategorikus megkülönböztetés visszaadása lehetetlenné válna, ha mindkettőt kizárásnak fordítanánk, hogy a magyar elzárkózás kifejezés olyan passzivitást sugalló asszociációkat kelthet (elvonul, félrehúzódik, visszahúzódik), ami a vizsgált társadalmi jelenség tekintetében nem lett volna szerencsés, valamint hogy a lezárás terminussal fejezhető ki leginkább a piacra vagy a hivatást űzők közé való bejutási lehetőség korlátozása, feltételekhez kötése.

A closure fogalmának jelentésrétegeiről és a magyar recepcióról szóló áttekintés, úgy véljük, meggyőzően demonstrálja, milyen nehéz helyzetbe kerülhetnek a fordítók, amikor egy másik kulturális közegben keletkezett és évszázados hagyományt magába olvasztó fogalmat kell magyar nyelvre átültetni, valamint reméljük, hogy áttekintésünk segíti a fogalom értelmezését és a körülötte zajló diskurzus összetartását.

\section{Hivatkozott irodalom}

Agevall, Ola (2016): Social closure: on metaphors, professions and a boa constrictor. In Professions and Metaphores. Understanding professions in society. Andreas Liljegren és Mike Saks (szerk.) London: Routledge. 63-76. DOI: https://doi.org/10.4324/9781315672045-5

Andorka Rudolf (1982): A társadalmi mobilitás változásai Magyarországon. Budapest: Gondolat.

Andorka Rudolf (1990): Hozzászólás a struktúra- és rétegződéskutatások vitájához a Replikában. Replika (2): 11-17.

Andorka Rudolf (1996): „Az eredmények azt mutatják, hogy a születéskorlátozás már 1790 körül megjelent Magyarországon." Beszélgetés Andorka Rudolf szociológussal. Aetas 11(4): 111-120.

Andorka Rudolf (2006a): „...megtanítottak arra, hogy tanulni és dolgozni kel”. Javorniczky István beszélgetése Andorka Rudolffal. 2. rész. Századvég, Új folyam (40): 133-178.

Andorka Rudolf (2006b): Bevezetés a szociológiába. Spéder Zsolt (szerk.) Budapest: Osiris.

Bendix, Reinhard (1974): Inequality and Social Structure: A Comparison of Marx and Weber. American Sociological Review 39(2): 149-161.

Böröcz József (1997): Stand Reconstructed. Contingent Closure and Institutional Change. Sociological Theory 15(3): 215-248. DOI: https://doi.org/10.1111/0735-2751.00033

Böröcz József (2001): Change Rules. American Journal of Sociology 106(4): 1152-1168. DOI: https://doi. org/10.1086/320303

Böröcz József (2002): A határ: társadalmi tény. Replika (47-48): 133-142.

Böröcz József (2017 [1997]): „Státusz” - „rendiesség” - „rendiség”. A feltételes társadalmi kirekesztés/beengedés és az intézmény-átalakulás szociológiája. (Ford.: Laszkács Ágnes) In uő Hasitott fa. A világrendszer-elmélettöl a globális struktúraváltásokig. Budapest: L’Harmattan-Eszmélet, 219-267.

Collins, Randall (1976): Review of The Social Analysis of Class Structure, edited by Frank Parkin. Contemporary Sociology 5(1): 85-87.

Collins, Randall (1990): Market closure and the conflict theory of professions. In Professions in Theory and History. Rethinking the Study of the Professions. Michael Burrage és Rolf Torstendahl (szerk.). London: SAGE Publications Ltd. 24-43.

Éber Márk Áron: Összezárunk, tehát vagyunk. A feltételes társadalmi kizárás és beengedés rendi szerveződései a kapitalista osztálytársadalmakban és az informalitás. Replika (115-116): 119-129. DOI: https://doi. org/10.32564/115-116.5 
Erdélyi Ágnes (1993): Max Weber Amerikában. Weber hatása és fogadtatása az angol-amerikai filozófiában és társadalomtudományban. Budapest: Scientia Humana.

Erdélyi Ágnes (2003): A társadalmi világ ideáltipikus felépítése. In A társadalmi világ ideáltipikus felépitése. Tanulmányok. Erdélyi Ágnes (szerk.) Budapest: Typotex.

Farkas János (1975): Szociológiai világkongresszus Kanadában. Gazdaság és Jogtudomány 9(1-2): 219-239.

Feleky Gábor (1996): A fehérgallér színeváltozásai. Egy foglalkozási aggregátum a „Marx-Weber erőtérben” és azon túl. Szociológiai Szemle 6(2) 3-31.

Freidson, Eliot (2001): Professionalism. The Third Logic. Cambridge: Polity Press.

Harrits, Gitte Sommer (2014): Professional Closure Beyond State Authorization. Professions and Professionalism 4(1): 1-17. DOI: https://doi.org/10.7577/pp.567

Horváth Ágnes (1988): Életesélyek asszimetriája. A megértés körének változása és a kortárs struktúraelmélet. Társadalomkutatás 6(4): 50-59.

Kolosi Tamás (1987): Tagolt társadalom. Struktúra, rétegződés, egyenlötlenség Magyarországon. Budapest: Gondolat.

Liljegren, Andreas (2016 [2012]): Key metaphors in the sociology of professions: occupations as hierarchies and landscapes. In Professions and Metaphores. Understanding professions in society. Andreas Liljegren és Mike Saks (szerk.) London: Routledge. 10-30. DOI: https://doi.org/10.4324/9781315672045-2

Magos Gergely (2017): Mérlegen a hivatások. A professzionalizációs paradigma historiográfiája. Aetas 32(2): $138-157$.

Murphy, Raymond (1983): The Struggle for Scholarly Recognition: The Development of the Closure Problematic in Sociology. Theory and Society 12(5): 631-658. DOI: https://doi.org/10.1007/bf00158646

Murphy, Raymond (1984): The Structure of Closure: A Critique and Development of the Theories of Weber, Collins, and Parkin. The British Journal of Sociology 35(4): 547-567. DOI: https://doi.org/10.2307/590434

Murphy, Raymond (1985): Exploitation or Exclusion? Sociology 19(2): 225-243. DOI: https://doi.org/10.1177/003 8038585019002006

Murphy, Raymond (1986a): The concept of class in closure theory: learning from rather than falling into the problems encountered by neo-marxism. Sociology 20(2): 247-264. DOI: https://doi.org/10.1177/00380385860 20002006

Murphy, Raymond (1986b): Weberian Closure Theory: A Contribution to the Ongiong Assessment. The British Journal of Sociology 37(1): 21-41. DOI: https://doi.org/10.2307/591049

Nagy J. Endre (2003): A struktúraelmélet weberi koncepciója és néhány interpretációja. In Szociokalandozások. Válogatott szociológiai tanulmányok. Szombathely: Savaria University Press. 15-79.

Parkin, Frank (1974): Strategies of Social Closure in Class Formation. In The Social Analysis of Class Structure. Frank Parkin (szerk.) London: Tavistock Publications, 1-18. DOI: https://doi.org/10.4324/9781351067904-1

Parkin, Frank (1979): Marxism and Class Theory. A Bourgeois Critique. New York: Columbia University Press.

Parkin, Frank (2013 [1974]): A társadalmi elzárkózás stratégiái az osztályok kialakulásában. (Ford.: Berényi Eszter.) In Társadalmi rétegződés olvasókönyv. (E-book.) Angelusz Róbert, Gecser Ottó és Éber Márk Áron (szerk.). Budapest: ELTE Társadalomtudományi Kar. 91-100. Interneten:https://regi.tankonyvtar.hu/hu/tartalom/ tamop425/0010_2A_19_Tarsadalmi_retegzodes_olvasokonyv_szerk_Gecser_Otto/ch03s03.html

Saks, Mike (2010): Analyzing the Professions: The Case for the Neo-Weberian Approach. Comparative Sociology 9(6): 887-915. DOI: https://doi.org/10.1163/156913310x522624

Saks, Mike (2012): Defining a Profession: The Role of Knowledge and Expertise. Professions and Professionalism 2(1): 1-10. DOI: https://doi.org/10.7577/pp.v2i1.151

Somlai Péter (1993): Angol - magyar magyar - angol szociológiai szótár. Budapest: Balassi.

Swedberg, Richard és Ola Agevall (2016 [2005]): The Max Weber Dictionary. Key Words and Central Concepts. Stanford, CA: Stanford University Press. DOI: https://doi.org/10.1515/9781503600225

Szelényi Iván (1983): Az amerikai szociológiáról. Interjú Szelényi Ivánnal. (Készítette: Papp Zsolt). Szociológia 12(3): 307-317.

Tardos Róbert (2015): Elismerés, presztízs, kizárás, társadalmi tőke. Replika (92-93): 59-76.

Weber, Max (1922 [1913]): Über einige Kategorien der verstehenden Soziologie. In Gesammelte Aufsätze für Wissenschaftslehre. Tübingen: J. C. B. Mohr (Paul Siebeck).

Weber, Max (1978): Economy and Society. An Outline of Interpretative Sociology. Guenther Roth és Claus Wittich (szerk.) Berkeley: University of California Press.

Weber, Max (1980): Wirtschaft und Gesellschaft. Grundriß der verstehenden Soziologie. Johannes Winckelmann (szerk.) Tübingen: J. C. B. Mohr (Paul Siebeck).

Weber, Max (1992): Gazdaság és társadalom. A megértő szociológia alapvonalai 2/1. (Ford. és szerk: Erdélyi Ágnes.) Budapest: Közgazdasági és Jogi Könyvkiadó. 
Weber, Max (2003 [1913]): A megértő szociológia néhány kategóriájáról. Tanulmányok. (Ford.: Erdélyi Ágnes.) In A társadalmi világ ideáltipikus felépitése. Erdélyi Ágnes (szerk.) Budapest: Typotex.

Tátrai Viktor

PhD-hallgató, ELTE BTK Társadalom- és Gazdaságtörténeti Doktori Program 